\title{
Similarities and Differences between the Responses of Rat Sensory Neurons to Noxious Heat and Capsaicin
}

\author{
Istvan Nagy ${ }^{1,2}$ and Humphrey P. Rang ${ }^{1}$ \\ ${ }^{1}$ Novartis Institute for Medical Sciences, London, WC1E 6BN, United Kingdom, and '2Department of Anesthetics, Imperial \\ College of Science, Technology and Medicine, School of Medicine, St. Mary's Hospital, London, W2 1NY, \\ United Kingdom
}

We have compared the membrane response of rat primary sensory neurons to capsaicin and noxious heat, using electrophysiological and ion flux measurements. Our aim was to determine whether, as recently proposed, the same molecular entity accounts for excitation by both types of stimulus.

The properties of the ion channels activated by heat and capsaicin show many similarities but also important differences. The calcium permeability of heat-activated channels is lower than that of capsaicin-activated channels. Distinct single chan- nels respond to heat or capsaicin, and only a few show dual sensitivity. At the whole-cell level, individual cells invariably show dual sensitivity, but the amplitudes of the responses show little correlation.

We conclude that distinct molecular entities, which are both likely to be derived from the VR1 gene product, account for the membrane responses to heat and capsaicin.

Key words: sensory neurons; capsaicin; heat; VR1; wholecell; single-channel
Primary afferent neurons that respond to noxious stimuli belong mainly to the class of C-polymodal nociceptors. They are sensitive to various types of stimulus, including chemicals such as capsaicin (collectively known as vanilloids), temperatures in the noxious range $\left(>45^{\circ} \mathrm{C}\right)$, and mechanical stimuli of moderate to high intensity (Szolcsanyi et al., 1988; Campbell and Meyer, 1996). Studies on the membrane responses of these neurons to vanilloids (Bevan and Szolcsanyi, 1990; Bevan and Docherty, 1993; Oh et al., 1996) have shown that these compounds act by opening a specific class of nonselective cation channels. The discovery of specific binding of a potent vanilloid agonist, resiniferatoxin, to the membranes of dorsal root ganglion neurons (Szallasi and Blumberg, 1990), and of a competitive vanilloid antagonist, capsazepine (Bevan et al., 1992), proved the existence of a specific receptor, which was recently cloned and designated VR1 (Caterina et al., 1997). Membrane responses to noxious heat had previously been recorded from sensory neurons grown in culture (Cesare and McNaughton, 1996; Kirschstein et al., 1997; Reichling and Levine, 1997), and work by Caterina et al. (1997) and Tominaga et al. (1998) showed that when VR1 was expressed in oocytes or in a mammalian cell line, these cells showed sensitivity to noxious heat as well as to vanilloids, leading to the suggestion that the same molecular entity-the VR1 gene product-functions as the "receptor" for both vanilloids and noxious heat. VR1 was shown to function as a membrane ion channel, gated by vanilloid agonists and by noxious heat, and to be expressed mainly in small-diameter sensory neurons (Tominaga et al., 1998; Michael and Priestley, 1999), leading to the suggestion that VR1 functions as a physiological heat transducer in sensory nerve terminals.

Consistent with this hypothesis, we reported recently that all of

Received June 21, 1999; revised Sept. 20, 1999; accepted Sept. 30, 1999.

Correspondence should be addressed to Istvan Nagy, Department of Anesthetics, Imperial College of Science, Technology and Medicine, School of Medicine, St. Mary's Hospital, London, W2 1NY, UK. E-mail: i.nagy@ic.ac.uk.

Copyright (C) 1999 Society for Neuroscience 0270-6474/99/1910647-09\$05.00/0 the small- to medium-sized rat dorsal root ganglion (DRG) neurons that respond to temperatures in the noxious range [average threshold $45.3^{\circ} \mathrm{C}$, designated low-threshold (LT) cells] are also capsaicin-sensitive, although there is a second class of heatsensitive neurons, larger in size, with a threshold of $51^{\circ} \mathrm{C}$ [highthreshold (HT) cells], which are insensitive to capsaicin, (Nagy and Rang, 1999) and presumably possess a heat-sensitive mechanism distinct from VR1. This could correspond to VRL-1, a VR1 homolog that codes for a high-threshold heat-activated channel that is insensitive to capsaicin (Caterina et al., 1999).

The present study was designed to test the hypothesis that heat and capsaicin activate the same membrane channels in lowthreshold cells, by comparing the membrane responses of rat sensory neurons to these stimuli at the whole-cell and singlechannel level. We conclude that although there are close similarities, the channels activated by heat and capsaicin are in fact different, possibly representing molecular variants of the VR1 gene product.

Preliminary reports of some of this work have been published previously (Nagy and Rang, 1997, 1998).

\section{MATERIALS AND METHODS}

Cell preparation. Cultures of DRG neurons were prepared according to Lindsay (1988). Adult rats (150-200 gm) were killed with $\mathrm{CO}_{2}$, and DRGs from all segments were removed and collected in Ham's Nutrient Mixture F14 (Imperial Laboratories) culture medium containing L-glutamine ( $2 \mathrm{~mm}$; Life Technologies, Gaithersburg, MD), penicillin/ streptomycin (Life Technologies; $50 \mathrm{IU} / \mathrm{ml}$ penicillin and $50 \mu \mathrm{g} / \mathrm{ml}$ streptomycin), and 4\% Ultroser G (Life Technologies). Ganglia were then incubated in culture medium containing collagenase (Type IV, $0.16-0.32 \mathrm{IU} / \mathrm{ml}$; Sigma, St. Louis, MO) for $3 \mathrm{hr}$ at $37^{\circ} \mathrm{C}$ in a $3 \% \mathrm{CO}_{2}$ incubator. After several washes DRG neurons were dissociated by trituration with a fire-polished Pasteur pipette. Cells were spun through sterile $15 \%$ bovine serum albumin (Sigma) and plated on glass coverslips coated with poly-DL-ornithine. DRG neurons were cultured for $1-5 \mathrm{~d}$ in F14 medium containing $50 \mathrm{ng} / \mathrm{ml}$ nerve growth factor (NGF) (Promega, Madison, WI) at $37^{\circ} \mathrm{C}$ in the presence of $3 \% \mathrm{CO}_{2}$.

Superior cervical ganglion (SCG) neurons were cultured according to Leaney et al. (1997). Sixteen-day-old rats were killed with $\mathrm{CO}_{2}$ and 
decapitated. The ganglia were dissected, cleaned of connective tissue, and incubated in Leibovitz L-15 culture medium (Sigma) containing collagenase (Sigma; $400 \mathrm{IU} / \mathrm{ml}$ ) for $15 \mathrm{~min}$, then transferred to medium containing trypsin (Sigma; $1 \mathrm{mg} / \mathrm{ml}$ ) for $30 \mathrm{~min}$, incubations being carried out at $37^{\circ} \mathrm{C}$ in $6 \% \mathrm{CO}_{2}$ incubator. Ganglia were washed and triturated with a fire-polished Pasteur pipette. Cells were plated on glass coverslips coated with poly-DL-ornithine and laminin, and cultured for $1-5 \mathrm{~d}$ in the presence of $6 \% \mathrm{CO}_{2}$ at $37^{\circ} \mathrm{C}$ in $\mathrm{L}-15$ medium containing $\mathrm{NaHCO}_{3}(24 \mathrm{~mm})$, fetal calf serum $(0.85 \%$, Life Technologies), glucose (38 mM), L-glutamine (2 mM, Life Technologies), penicillin/streptomycin (100 IU penicillin and $100 \mu \mathrm{g} / \mathrm{ml}$ streptomycin, Life Technologies), and NGF (50 ng/ml, Sigma).

Electrophysiology. Coverslips were placed in a recording chamber superfused by $37 \pm 0.5^{\circ} \mathrm{C}$ bath solution $(1 \mathrm{ml} / \mathrm{min})$. Recordings of wholecell currents under voltage clamp were made by standard techniques with an Axopatch 200A amplifier (Axon Instruments) and PCs running the pCLAMP6 and AxoScope software packages (Axon Instruments). For whole-cell recording, the capacitance transient and the series resistance were compensated to $>80 \%$ before each recording. Single-channel recordings were made in either the cell-attached or inside-out configuration (Hammill et al., 1981). Electrodes of $\sim 5 \mathrm{M} \Omega$ were pulled from borosilicate glass capillaries (Clark Electromedical Instruments) and fire-polished. For single-channel recordings, electrodes were coated with Sylgard (Dow Corning). Recordings were filtered at $2 \mathrm{kHz}$, digitized at 4 $\mathrm{kHz}$ for whole-cell or $16.6 \mathrm{kHz}$ for single-channel recordings with a DigiData 1200 interface, and stored on hard disk.

The standard bath solution contained (in $\mathrm{mM}$ ): $\mathrm{NaCl} 130, \mathrm{KCl} \mathrm{10}$, $\mathrm{MgCl}_{2} 1.26, \mathrm{CaCl}_{2} 1.26$, glucose 10, HEPES 10 (pH 7.4, adjusted with $\mathrm{NaOH}$ ). For whole recordings, the pipette solution contained (in $\mathrm{mm}$ ): $\mathrm{NaCl} 10, \mathrm{KCl} 130, \mathrm{MgCl}_{2}$ 1.26, EGTA 1, HEPES 10, (pH 7.4, adjusted with $\mathrm{KOH}$ ). For ionic-selectivity studies, $\mathrm{NaCl}$ in the pipette solution and $\mathrm{KCl}$ in the bath solution were omitted, and the $\mathrm{KCl}$ in the pipette solution was replaced by $130 \mathrm{~mm} \mathrm{CsCl}$. In some experiments either $\mathrm{Na}^{+}$ was replaced by equimolar $N$-methyl-D-glucamine (NMDG) or the $\mathrm{CaCl}_{2}$ concentration was altered in the bath solution. The holding membrane potential was $-60 \mathrm{mV}$. Reversal potentials of whole-cell currents were established by linear voltage ramps $(+40$ to $-100 \mathrm{mV}$ in $0.5 \mathrm{sec})$ generated by the pClamp6 software. The potential was held at $+40 \mathrm{mV}$ for $0.2 \mathrm{sec}$ at the start of the ramp to inactivate voltage-gated inward currents as far as possible. Cells that showed inflections on the control current-voltage $(I-V)$ curve, indicative of such currents, were not used for estimation of reversal potentials. The relative ion permeabilities were calculated by using the Goldman-Hodgkin-Katz equations (Lewis, 1979; Hille, 1992). The experiments were performed on the lowthreshold, capsaicin-sensitive group of cells (Nagy and Rang, 1999), defined as those that produced an inward current of $>100 \mathrm{pA}$ in response to $2 \mu \mathrm{M}$ capsaicin. To test the effect of inhibitors (ruthenium red and capsazepine) on the response of the neurons to capsaicin and heat, brief stimuli $\left(2 \mathrm{sec}\right.$ at $49^{\circ} \mathrm{C}$, or $1 \mathrm{sec}$ perfusion with $2 \mu \mathrm{M}$ capsaicin at $\left.37^{\circ} \mathrm{C}\right)$ were applied every $2 \mathrm{~min}$. EGTA $(5 \mu \mathrm{M})$ was added to the pipette solution to minimize increases in intracellular calcium concentration and thereby reduce desensitization. The inhibitor was added immediately after the first (control) response, and the second (test) response was used to measure the degree of inhibition. With no inhibitor added, the second response to capsaicin averaged $79.5 \pm 11.5 \%(n=6)$ of the first, whereas the second response to heat averaged $82.1 \pm 4.4 \%(n=7)$ of the first. The effects of inhibitors were corrected for these desensitization factors.

Single-channel recordings were performed in cell-attached patch or inside-out patch configuration established after giga-seal formation (Hammill et al., 1981). To ensure that the cell was fully depolarized, the bath solution contained (in $\mathrm{mM}$ ): $\mathrm{K}$-aspartate $115, \mathrm{KCl} 15, \mathrm{MgCl}_{2} 1.26$,

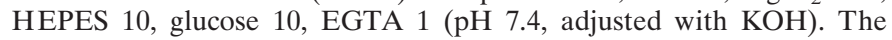
composition of the pipette solution was (in $\mathrm{mM}$ ): $\mathrm{NaCl} \mathrm{130,} \mathrm{KCl} 10$, $\mathrm{MgCl}_{2} 1.26, \mathrm{CaCl}_{2} 1.26 \mathrm{HEPES} 10$ (pH 7.4, adjusted with $\mathrm{NaOH}$ ). The junction potential was compensated, and the pipette potential was set to $+60 \mathrm{mV}$. The voltage dependence of the single-channel currents was established by applying $200 \mathrm{msec}$ voltage steps to vary the pipette potential between +100 and $-40 \mathrm{mV}$. Analysis of single-channel records was performed by means of SCAN and EKDIST software (Colquhoun and Sigworth, 1995), kindly provided by Prof. D. Colquhoun (Department of Pharmacology, University College London, UK). Because the mean open time of heat-activated channels was brief (see Results), their amplitudes were often reduced by the low-pass filter that was needed to diminish background noise. By correcting for the characteristics of the filter, the SCAN program gives improved estimates of the amplitude and duration of brief openings.

Heat stimuli were applied by perfusing bath solution at $\sim 0.5 \mathrm{ml} / \mathrm{min}$ through a plastic tube positioned $<100 \mu \mathrm{m}$ from the cell. The solution was passed through a silver heat exchanger the temperature of which was regulated by a feedback-controlled Peltier element. Heat stimulation was applied either as a pulse produced by switching between heat exchangers held at $37^{\circ} \mathrm{C}$ and $52^{\circ} \mathrm{C}$, respectively, or by ramping the temperature of the heat exchanger from $37^{\circ}$ to $52^{\circ} \mathrm{C}$ over $10 \mathrm{sec}$ with a temperature controller/power supply (Marlow Instruments). The temperature of the stimulating solution, which was monitored by means of a fine thermocouple at the tip of the perfusion tube, increased from $37^{\circ}$ to $52^{\circ} \mathrm{C}$. With "pulse" stimulation, the new temperature was reached within $2-3 \mathrm{sec}$. Drugs were applied to the cells through the same perfusion system at $37^{\circ} \mathrm{C}$, and antagonists were applied for 2 min before the test stimulation.

The longest diameter of the neurons in some experiments was measured by an eyepiece graticule.

${ }^{45} \mathrm{C}$ a uptake experiments. The method described by Wood et al. (1988) was used to measure the increase in ${ }^{45} \mathrm{C}$ a uptake evoked by capsaicin or heat. In brief, DRG neuron cultures $(\sim 300$ cells per sample) on glass coverslips were washed for $10 \mathrm{~min}$ at $37^{\circ} \mathrm{C}$ in physiological buffer containing no added $\mathrm{Ca}^{2+}$. They were then transferred for $10 \mathrm{~min}$ to buffer containing ${ }^{45} \mathrm{Ca}(\sim 1 \mu \mathrm{Ci} / \mathrm{ml})$ that either contained capsaicin at a given concentration or was maintained at raised temperature (up to $52^{\circ} \mathrm{C}$ ). The coverslips were then washed three times ( 2 min washes) in buffer containing $2 \mathrm{mM} \mathrm{CaCl}_{2}$ and placed in plastic counting vials to which $5 \mathrm{ml}$ scintillant was added for determination of the ${ }^{45} \mathrm{Ca}$ activity by liquid scintillation counting. The radioactivity in each sample was expressed relative to the mean radioactivity of cells that had been exposed to ${ }^{45} \mathrm{Ca}$-containing buffer at $37^{\circ} \mathrm{C}$. Most experiments were run with quadruplicate samples.

The composition of the Ca-free physiological buffer was (in mM): $\mathrm{NaCl}$ 135, $\mathrm{KCl} 5$, glucose 10, HEPES 10, brought to $\mathrm{pH} 7.4$ with $\mathrm{NaOH}$.

Cell viability determination. To determine whether cells were killed by raised temperatures, combined staining with two fluorescent markers was used (Viability/cytotoxicity kit, Molecular Probes, Eugene, OR). Intact cells trap calcein AM, producing green fluorescence, whereas ethidium bromide enters only damaged cells, producing orange fluorescence. Cell cultures were exposed to normal physiological buffer (as above, plus $\mathrm{CaCl}_{2} 2 \mathrm{mM}, \mathrm{MgCl}_{2} 2 \mathrm{mM}$ ) at various temperatures for $10 \mathrm{~min}$, returned to room temperature for $30 \mathrm{~min}$, then stained for $45 \mathrm{~min}$ with calcein $\mathrm{AM}$ $(1 \mu \mathrm{M})$, which gives green fluorescence in intact cells, and ethidium bromide $(2 \mu \mathrm{M})$, which gives orange fluorescence in damaged cells. The dyes were made up in physiological buffer. After they were washed in physiological buffer, the cells were photographed with a fluorescence microscope (Nikon).

Statistical analyses were performed by the Clinstat software package. Data are expressed as mean \pm SEM.

\section{RESULTS}

\section{Whole-cell recordings}

Capsaicin application was used to distinguish low-threshold heatsensitive DRG cells (Nagy and Rang, 1999). Capsaicin (2 $\mu \mathrm{M}$ for $1.5 \mathrm{sec}$ at $37^{\circ} \mathrm{C}$ ) evoked inward current in 109 of 355 neurons selected at random (31\%). Other distinct populations were (1) insensitive cells that responded to neither capsaicin nor heat (163 of $355,46 \%$ ) and (2) high-threshold heat-sensitive cells that were insensitive to capsaicin ( 83 of $355,23 \%$ ). The results presented here were obtained from cells of the low-threshold type. The average amplitude of the inward current evoked by capsaicin, in cells clamped at $-60 \mathrm{mV}$, was $1.39 \pm 0.11 \mathrm{nA}(n=109)$. The mean threshold of the heat-evoked current, measured from the temperature at which the inward current appeared during a heat ramp, was $45 \pm 0.2^{\circ} \mathrm{C}(n=109)$ (Fig. $\left.1 A, B\right)$, and the maximum amplitude recorded at the end of the standard heat $\operatorname{ramp}\left(52^{\circ} \mathrm{C}\right)$ was $2.22 \pm 0.14 \mathrm{nA}(n=109)$. Capsaicin-sensitive cells were among the small- and medium-sized neurons, with an average diameter of $22.8 \pm 0.5 \mu \mathrm{m}(n=109)$. DRG neurons classed as heat-insensitive usually showed a small, linearly increasing inward current in response to a temperature ramp, averaging $0.1 \mathrm{nA}$ at 
$\mathbf{A}$
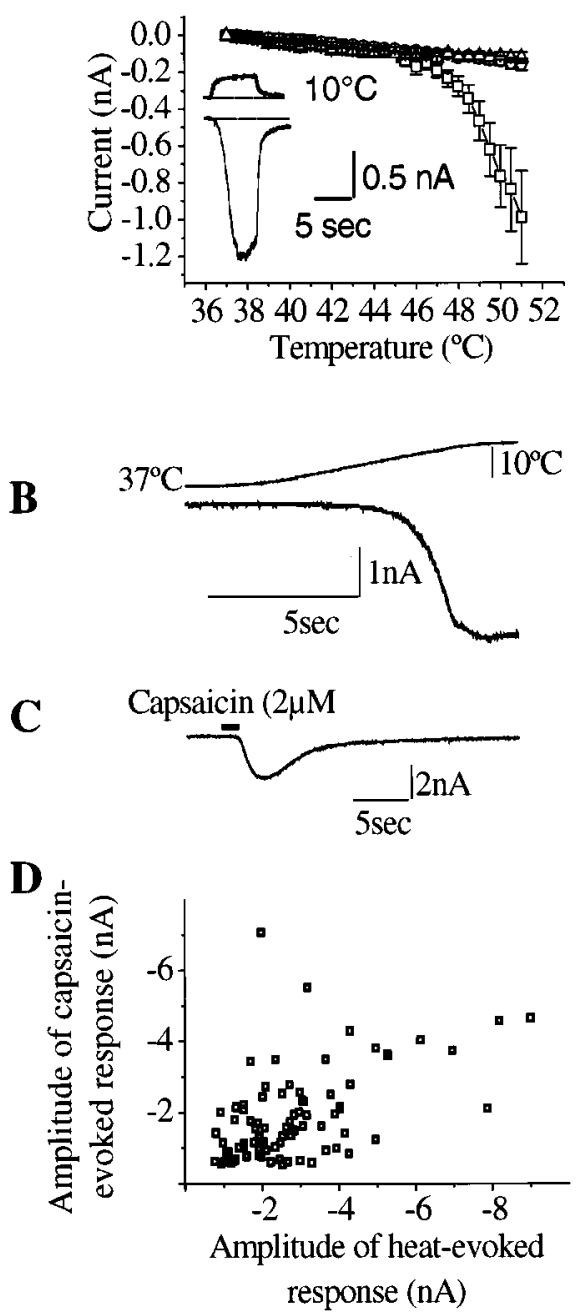

Figure 1. A, Whole-cell voltage-clamp recordings obtained from cultured dorsal root ganglion and superior cervical ganglion neurons reveal a subpopulation of DRG cells that produce inward cationic currents when stimulated by heat in the noxious range. Averaged current temperature plots of noxious heat-sensitive DRG neurons (squares, $n=22$ ), noxious heat-insensitive DRG neurons (triangles, $n=20$ ), and SCG neurons (circles, $n=17$ ). Inset shows recording from a noxious heat-sensitive DRG cell. Top and bottom traces are temperature and current recordings, respectively. Holding potential: $-60 \mathrm{mV}$. $B$, Heat ramp from $37-52^{\circ} \mathrm{C}$ $\left(1.75^{\circ} \mathrm{C} / \mathrm{sec}\right)$ evokes specific heat-activated inward current that increases sharply above $45^{\circ} \mathrm{C}$. $C$, Capsaicin superfusion $(2 \mu \mathrm{M}, 2 \mathrm{sec})$ to the same neuron as $B$ also produces an inward current. $D$, Relationship between maximum amplitudes of currents evoked by the standard heat ramp stimulation $\left(37-52^{\circ} \mathrm{C}, 1.75^{\circ} \mathrm{C} / \mathrm{sec}\right)$ and subsequent capsaicin application $(2 \mu \mathrm{M}, 2 \mathrm{sec})$. Correlation coefficient, $r^{2}=0.53$.

the end of the ramp (Fig. $1 A$ ), which was very similar to the response seen in all superior cervical ganglion neurons tested. This was taken to be a nonspecific response to heating and was not analyzed further.

\section{Correlation of heat and capsaicin sensitivity}

If heat and capsaicin act on the same membrane channels, a close correlation between the amplitudes of the two responses in individual cells would be predicted. Figure $1 D$ shows data for 86 capsaicin-sensitive cells (defined as those giving a response $>0.1$ $\mathrm{nA}$ when tested with $2 \mu \mathrm{M}$ capsaicin) that were also tested with a
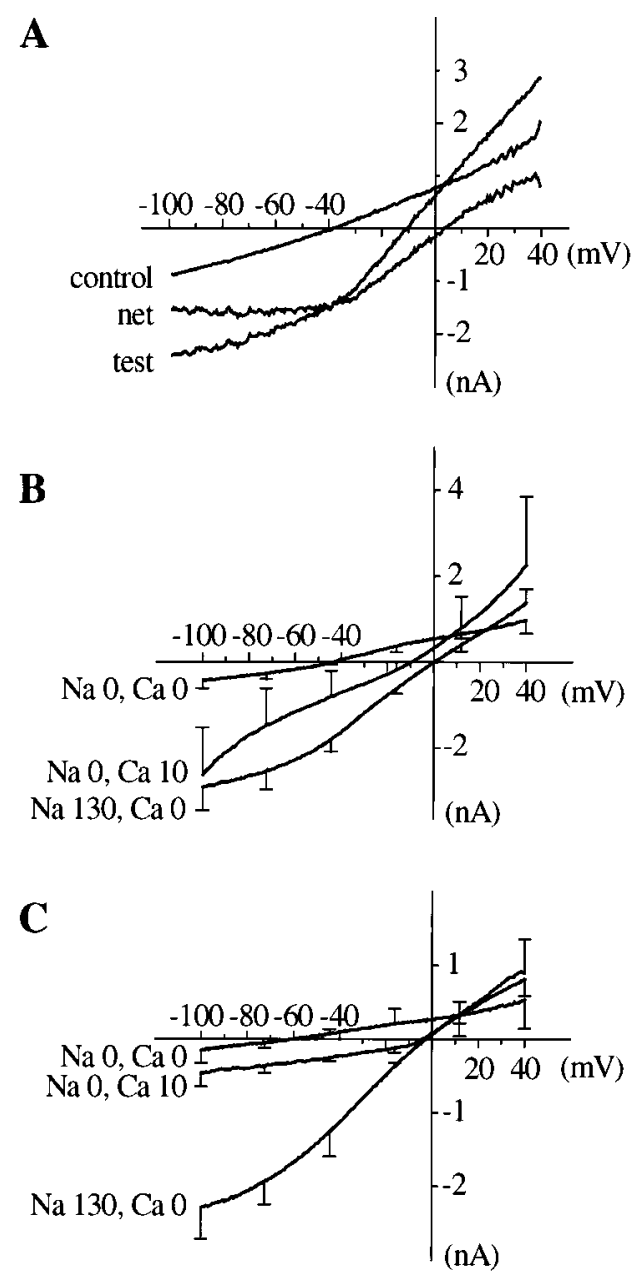

Figure 2. Current-voltage relationship of heat- and capsaicin-evoked currents established by voltage ramps (from +40 to $-100 \mathrm{mV}, 500 \mathrm{msec}$ ). The pipette solution contained $\mathrm{Cs}^{+}$in place of $\mathrm{K}^{+}$to eliminate voltageactivated $\mathrm{K}$ currents. $A$, Estimation of the net heat-activated $I-V$ curve by digital subtraction of the control from the test curve. $B$, Averaged net $I-V$ curves of heat-evoked currents recorded with different ionic composition of the bath solution. $C$, Averaged net $I-V$ curves of capsaicin-evoked currents recorded with different ionic composition of the bath solution. Error bars show SEM for points at intervals along the curves. Reversal potentials and number of experiments are given in Table 1 .

standard heat ramp. The correlation between the response amplitudes was weak, although statistically significant $\left(r^{2}=0.53 ; p<\right.$ 0.001).

\section{Ionic selectivity of channels}

For further characterization of the heat- and capsaicin-evoked currents in LT neurons, voltage ramps from +40 to $-100 \mathrm{mV}$ were applied before and during the heat- and capsaicin-induced currents. Net $I-V$ curves of the responses were constructed by subtracting the control current from that recorded during the response (Fig. 2A). As reported previously in heat- or capsaicinsensitive DRG neurons (Cesare and McNaughton, 1996; Oh et al., 1996) and in VR1-transfected human embryonic kidney (HEK) 293 cells (Tominaga et al., 1998), the net currents evoked by capsaicin and by heat show a similar degree of outward rectification, with low slope conductances at potentials negative to $-40 \mathrm{mV}$, and they have similar reversal potentials (Fig. 2B,C). The $I-V$ curves and mean reversal potentials for heat- and 


\begin{tabular}{|c|c|c|c|c|}
\hline \multicolumn{3}{|c|}{ External cations (mM) } & \multicolumn{2}{|c|}{ Reversal potential $(\mathrm{mV}) \pm \mathrm{SEM}$} \\
\hline $\mathrm{Na}^{+}$ & $\mathrm{NMDG}^{+}$ & $\mathrm{Ca}^{2+}$ & Heat & Capsaicin \\
\hline 130 & 0 & 1.26 & $0.9 \pm 1.4(17)$ & $-0.4 \pm 1.1(8)$ \\
\hline 130 & 0 & 0 & $2.1 \pm 1.4(13)$ & $-1.7 \pm 1.0(12)$ \\
\hline 0 & 130 & $-54.6 \pm 7.8(3)$ & $-58.4 \pm 5.0(3)$ & \\
\hline 0 & 130 & 1.26 & $-45.2 \pm 2.7^{*}(5)$ & $-36.2 \pm 2.1^{*}(5)$ \\
\hline 0 & 130 & 10 & $-13 \pm 1.4^{*}(4)$ & $-5.0 \pm 0.9^{*}(4)$ \\
\hline
\end{tabular}

Internal (pipette) solution contained $130 \mathrm{~mm} \mathrm{CsCl}_{2}$. $\mathrm{KCl}$ was omitted from external solutions.

*Values for heat and capsaicin differ significantly $(p<0.05)$. Estimated permeability ratios [based on bi-ionic equations (Hille, 1992, Eq. 1.13 and 13.11)]: for heat: $P_{\mathrm{Cs}} / P_{\mathrm{Na}} / P_{\mathrm{NMDG}} / P_{\mathrm{Ca}}=1.0: 1.08: 0.14: 1.29(0.95)$; for capsaicin: $P_{\mathrm{Cs}} / P_{\mathrm{Na}} /$ $P_{\text {NMDG }} / P_{\mathrm{Ca}}=1.0: 0.94: 0.11: 225(1.94)$. Estimates of $P_{\mathrm{Ca}} / P_{\mathrm{Cs}}$ shown in brackets were obtained by applying Equation A6 of Lewis (1979), which makes allowance for the estimated permeability of the channels to NMDG.

capsaicin-activated currents in various ionic solutions are shown in Figure 2 and Table 1. In these experiments, intracellular $\mathrm{K}^{+}$ was replaced by $\mathrm{Cs}^{+}$to eliminate the large outward $\mathrm{K}^{+}$current from the control $I-V$ curve, which makes the determination of the net currents unreliable at positive membrane potentials.

The reversal potentials of both currents were close to $0 \mathrm{mV}$ when the main extracellular and intracellular cations were $\mathrm{Na}^{+}$ and $\mathrm{Cs}^{+}$, respectively, implying that the permeability of the channel to $\mathrm{Na}^{+}$and $\mathrm{Cs}^{+}$was similar (Table 1). In the absence of $\mathrm{Ca}^{2+}$, replacement of extracellular $\mathrm{Na}^{+}$by NMDG reduced the amplitude of the currents, and shifted the reversal potential to approximately $-55 \mathrm{mV}$, with no significant difference between heat- and capsaicin-activated currents, implying that the permeability of the channel to NMDG is similar for both, although much less than the $\mathrm{Na}^{+}$permeability, as shown by the calculated permeability ratios given in Table 1 , which agree well with the values estimated by Cesare and McNaughton (1996). When $\mathrm{Na}^{+}$ was substituted by NMDG, addition of $1.3-10 \mathrm{mM} \mathrm{Ca}^{2+}$ shifted the reversal potential to more positive values, implying a relatively high permeability of the channels to $\mathrm{Ca}^{2+}$. In these solutions, the reversal potential for the capsaicin-activated current was significantly more positive than that of the heat-activated current, showing that the relative $\mathrm{Ca}^{2+}$ permeability of the channels is larger in the former case. Exact estimates are difficult, but calculations based on either the simple bi-ionic equation (Hille, 1992, Eq. 1.13 and 13.11), which disregards the contribution of NMDG, or the more complicated Lewis equation (Lewis, 1979, Eq. A6), which takes it into account, show that the $\mathrm{Ca}^{2+}$ permeability associated with capsaicin-activated currents is approximately double that of heat-activated currents, a difference in the same direction as that reported by Tominaga et al. (1998) for responses measured in VR1-transfected HEK293 cells.

\section{Pharmacological properties}

The effect of two known capsaicin antagonists-the competitive antagonist capsazepine (Bevan et al., 1992) and the nonselective channel blocking compound ruthenium red (Dray et al., 1990; Maggi et al., 1993)—on heat-evoked and capsaicin-evoked currents in low-threshold neurons is shown in Figure 3.

Ruthenium red inhibited the capsaicin-evoked current with an $\mathrm{IC}_{50}$ close to $1 \mu \mathrm{M}$ but produced a biphasic effect on the heatevoked current, increasing it significantly at concentrations below $1 \mu \mathrm{M}$ and inhibiting it at higher concentrations (Fig. 3C). Capsazepine (Fig. 3B,D) strongly inhibited capsaicin-evoked responses $\left(\mathrm{IC}_{50}<0.5 \mu \mathrm{M}\right)$ but was much less active against heatevoked currents, producing only slight inhibition at $10 \mu \mathrm{M}$.
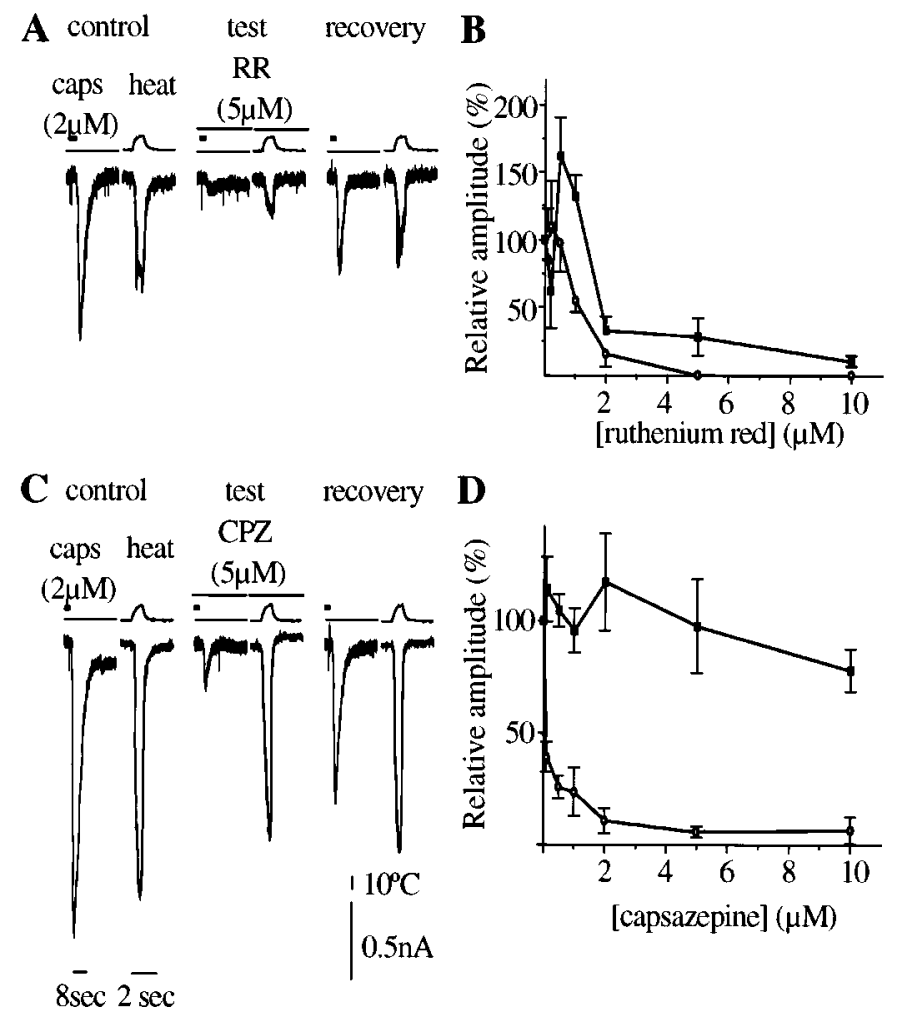

Figure 3. Effect of ruthenium red and capsazepine on capsaicin- and heat-evoked currents. In these experiments both capsaicin-evoked and heat stimulation were brief $(2 \mathrm{sec})$, and $5 \mathrm{~mm}$ EGTA was added to the pipette solution to reduce desensitization of subsequent responses. $A$, Ruthenium red $(R R)$ produces reversible reduction of both capsaicin- and heat-activated currents. $B$, Dose-response curve of ruthenium red on responses $( \pm$ SEM) to heat $(\boldsymbol{\square}, n=3-6)$ and capsaicin $(\bigcirc, n=3-6)$ currents. $\mathrm{IC}_{50}$ of RR for both currents is in the same range $(1-2 \mu \mathrm{M})$, although at low concentrations, RR significantly increased heat-induced current. $C$, Capsazepine selectively inhibited the capsaicin-evoked currents but had little effect on the heat-induced current. $D$, Dose-response curve of capsazepine on responses to heat $(\boldsymbol{\square}, n=4-6)$ and capsaicin $(\bigcirc$, $n=4-6)$.

\section{Calcium uptake}

Capsaicin (at $37^{\circ} \mathrm{C}$ ) evoked a graded increase in ${ }^{45} \mathrm{Ca}$ uptake, as reported in previous studies (Wood et al., 1988); the maximum effect was an average sevenfold increase over control (Fig. 4). Heating to temperatures above $46^{\circ} \mathrm{C}$ also produced an increase, 


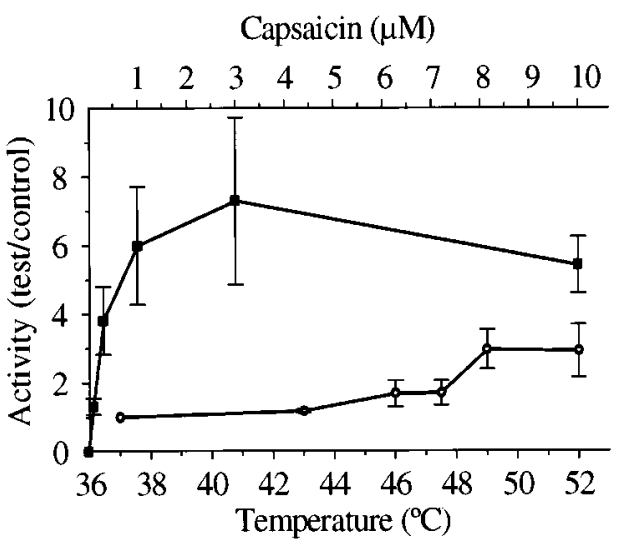

Figure 4. ${ }^{45} \mathrm{Ca}$ accumulation, expressed as relative activity $\left(\mathrm{cpm}_{\text {test }} /\right.$ $\left.\mathrm{cpm}_{\text {control }}\right) \pm$ SEM, by cultured DRG neurons induced by capsaicin ( $\boldsymbol{\square}$, $n=4-6)$ and heat $(\bigcirc, n=3-5)$.

maximally threefold at $49^{\circ} \mathrm{C}$, a level significantly lower than that achieved by capsaicin.

Because of the relatively small response to heat in this assay, the effect of inhibitors was not tested.

\section{Cell viability assay}

In electrophysiological studies, brief heating of the cells to $52^{\circ} \mathrm{C}$ appeared to produce no obvious irreversible effects. We tested for nonspecific cell damage at higher temperatures and longer exposure times, using a fluorescent labeling technique that detects damaged cells by the leakiness of their membranes to hydrophilic dyes (see Materials and Methods). When the cells were exposed to raised temperatures for $10 \mathrm{~min}$ in normal physiological buffer and then kept at room temperature for $30 \mathrm{~min}$, all of the neurons appeared viable after a $49^{\circ} \mathrm{C}$ challenge but were killed at $60^{\circ} \mathrm{C}$, graded degrees of damage being evident at intermediate temperatures.

\section{Single-channel recordings}

Single-channel activity evoked by heat was observed in 19 of 97 cell-attached patches of DRG cells (Fig. $5 A, B$ ), and in 25 of 161 excised inside-out patches (Fig. $5 F$ ). Channel activity was absent at $37^{\circ} \mathrm{C}$, and channel events stopped as soon as the temperature was restored to $37^{\circ} \mathrm{C}$ (Fig. $5 A$ ). None of the patches obtained from superior cervical ganglion neurons $(n=37)$ showed heatactivated channel activity (Fig. 5C). Capsaicin-activated channels were also recorded from 10 of 100 cell-attached patches (capsaicin included in the pipette solution, bath temperature $37^{\circ} \mathrm{C}$ ) and from 18 of 161 inside-out patches. In the majority of the patches $(\sim 70 \%)$, both heat and capsaicin induced multiple level of openings at $-60 \mathrm{mV}$ membrane potential.

Overall single-channel activity, expressed as the mean channel current, is plotted against temperature in Figure $5 E$. This curve does not differ significantly from the temperature-current curve obtained in whole-cell recordings. The single-channel currentvoltage relationship (Fig. $6 A, B$ ) was similar to that for whole-cell currents recorded under similar ionic conditions; both curves showed pronounced outward rectification at membrane potentials negative to $-40 \mathrm{mV}$, similar to that of capsaicin-activated channels (Fig. 6C,D). Detailed analysis of single-channel currents by the Scan software package was performed for nine heat-activated $\left(50^{\circ} \mathrm{C}\right)$ and 10 capsaicin-activated $\left(1 \mu \mathrm{M}\right.$ at $\left.37^{\circ} \mathrm{C}\right)$ membrane patches in which no multiple openings were observed. Typical amplitude and open and shut time distributions are shown in
A

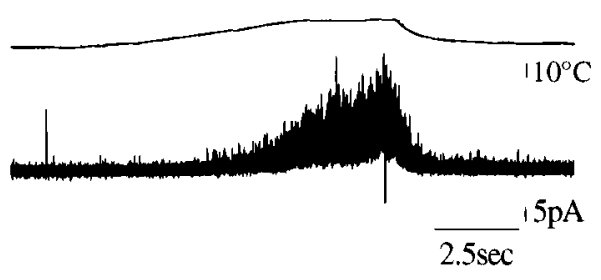

B

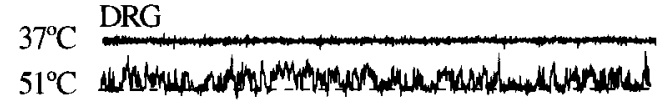

C

$37^{\circ} \mathrm{C}$

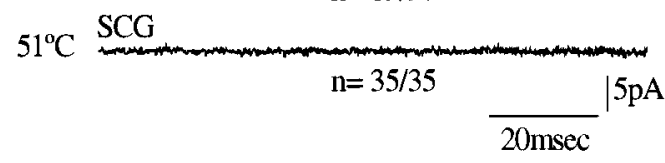

D

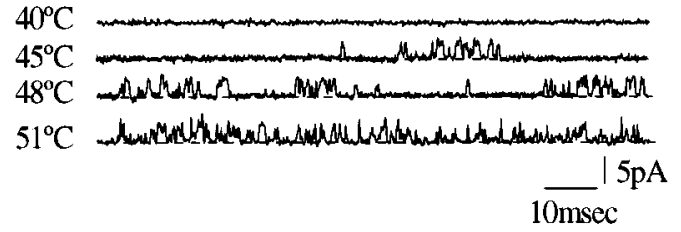

$\mathbf{E}$

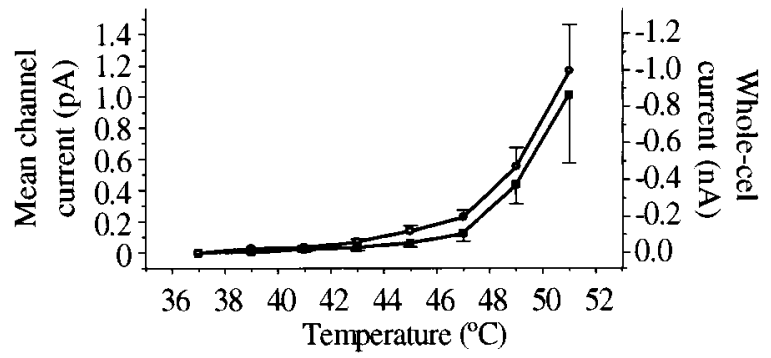

$\mathbf{F}$

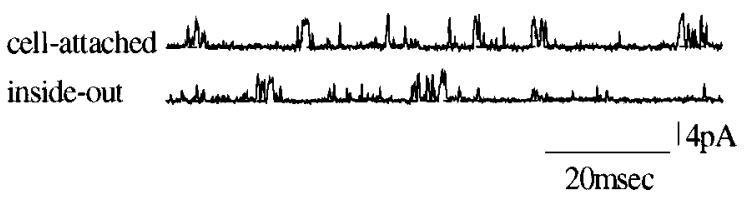

Figure 5. Single-channel recording from membrane patches expressing heat-sensitive ion channels in cell-attached patch and inside-out patch configuration. Bath solution in these experiments contained $130 \mathrm{mM} \mathrm{K}^{+}$, and the pipette solution contained $130 \mathrm{mM} \mathrm{Na}^{+}$. The pipette potential was set to $+60 \mathrm{mV}$. $A$, Heat ramp from $37^{\circ} \mathrm{C}$ to $51^{\circ} \mathrm{C}$ evokes multiple channel activity in cell-attached patch configuration $(n=19$ of 97$)$. The activity starts at $44^{\circ} \mathrm{C}$ and stops when the temperature returns to $37^{\circ} \mathrm{C}$. B. Sweeps $(100 \mathrm{msec})$ of a recording from a heat-sensitive membrane patch (cellattached configuration) showing channel activity (upward deflections) at $51^{\circ} \mathrm{C}$. $C$, SCG neuron membrane patch in cell-attached configuration, showing no heat-activated channel activity. $D$, Temperature dependence of channel activity in a cell-attached membrane patch stimulated by a slow heat ramp. The dotted line shows shut level. E, Mean single-channel current ( $\square$, mean \pm SEM of 8 cell-attached patches) as a function of temperature, compared with the mean whole-cell current $(\bigcirc$, mean of 23 cells). $F$, Heat-induced channel activity at $50^{\circ} \mathrm{C}$ in the same membrane patch, recorded in cell-attached and inside-out mode.

Figure 7. The results are summarized in Table 2. This analysis suggested the existence of two distinct amplitude levels for both heat- and capsaicin-activated channels (Fig. 7), the main level being significantly higher for heat (3.4 pA) than for capsaicin (2.8 pA). The low-amplitude channels accounted for an estimated average of 17 and $8 \%$ of the openings for heat and capsaicin, respectively, but were not detected in all patches. The open time distributions were well fitted by a single component, the average open time $\left(\tau_{\text {open }}\right)$ of heat-activated channels being significantly 

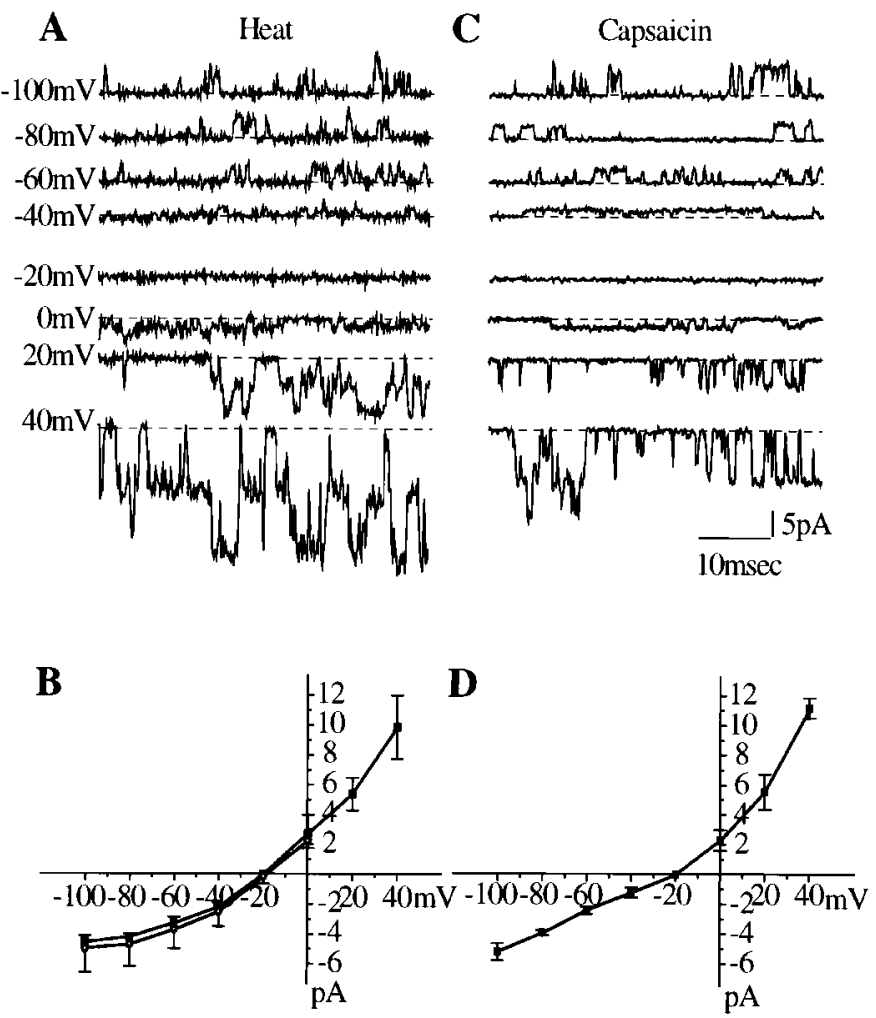

Figure 6. Single-channel current-voltage relationship of heat- and capsaicin-gated ion channels studied by applying voltage steps between -100 and $+40 \mathrm{mV}$. Pipette solution contained $130 \mathrm{~mm} \mathrm{NaCl}$; bath solution contained $130 \mathrm{~mm} \mathrm{KCl}$. A, Recordings of heat-induced singlechannel events at different membrane potentials in inside-out patch configuration. $B$, The single-channel $I-V$ curve of heat-activated channels in inside-out patches $(\boldsymbol{\square}, n=3)$, compared with that for whole-cell currents (open circles, $n=5$ ) recorded with the same internal and external solutions. Data for cell-attached patches (data not shown) were superimposable. The curves show outward rectification and reversal potentials close to $-20 \mathrm{mV}$, different from the values given in Table 1 , where $\mathrm{Cs}^{+}$ was the main internal cation. $C$, Channel activity in an inside-out membrane patch evoked by perfusion of capsaicin $(2 \mu \mathrm{M})$ to the inside surface at different membrane potentials. $D$, The $I-V$ curve of capsaicin induced single-channel current $(n=3)$ showing the same shape and reversal potential as in $B$. In single-channel recordings, the dotted line indicates shut state.

shorter $(0.41 \mathrm{msec})$ than that of capsaicin-activated channels (0.69 msec). The shut time distributions, as expected, were more complex and contained more than one component. The distributions were similar for capsaicin and for heat. In both cases, the most numerous events consisted of very brief closures of $<1 \mathrm{msec}$ but much longer closures also occurred. Quantitative analysis of the shut time distribution patterns was not performed, because interpretable data would require longer stretches of record and a systematic study with varying temperatures and capsaicin concentrations.

Expressing the open-channel characteristics (amplitude and $\left.\tau_{\text {open }}\right)$ for heat- and capsaicin-activated channels as ratios gives the following values for inside-out patches: amplitude (heat, $50^{\circ} \mathrm{C}$ )/amplitude $\left(\operatorname{cap}, 37^{\circ} \mathrm{C}\right)=1.21 ; \tau_{\text {open }}$ (heat, $\left.50^{\circ} \mathrm{C}\right) / \tau_{\text {open }}($ cap, $\left.37^{\circ} \mathrm{C}\right)=0.59$. To test whether these differences in single-channel characteristics could be attributed to the temperature difference rather than to the nature of the activating stimulus, capsaicinactivated channels recorded at $37^{\circ} \mathrm{C}$ and $50^{\circ} \mathrm{C}$ were compared in inside-out patches that showed no channel openings in response
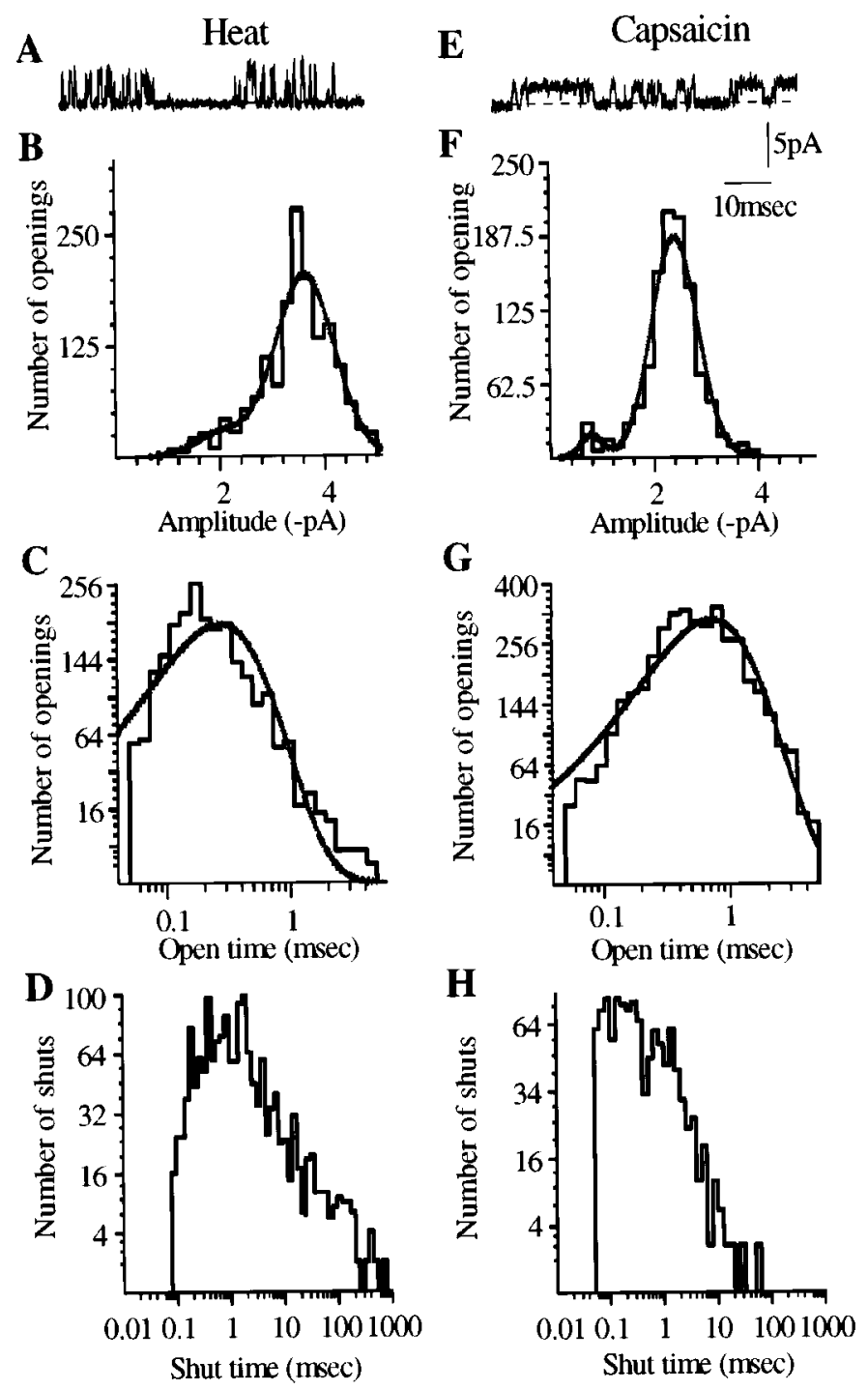

Figure 7. Comparison of the characteristics of single-channel events produced by heat and capsaicin recorded from inside-out patches at -60 $\mathrm{mV}$. Single-channel events were fitted by SCAN and analyzed by EKDIST software. SCAN estimates the amplitudes of single-channel events after correcting for low-pass filtering, and EKDIST plots the frequency distribution of the duration of individual open and closed states. $A, E$, Single-channel events induced by heat and capsaicin. $B, F$, Amplitude histogram of channel events, fitted by the maximum likelihood method. Curve fitting reveals a significant number of low-amplitude events, in addition to the main level, for both heat- and capsaicin-evoked activity. Both conductance levels are smaller for capsaicin than for heat (Table 2). $C, G$, Open time distribution of channel openings induced by heat $(C)$ and capsaicin $(G)$. Both distributions can be fitted by a single component. $D, H$, Shut time distribution of channel activity produced by heat and capsaicin. In most cases, as here, the fitted distribution indicated the presence of several components, which could not be reliably estimated from the available data. Ordinates of open and shut time distributions are plotted on square root scale, and abscissae are plotted on a logarithmic scale (Colquhoun and Sigworth, 1995).

to heat alone (see below). Two such experiments were analyzed successfully: the ratio amplitude (cap, $50^{\circ} \mathrm{C}$ )/amplitude (cap, $37^{\circ} \mathrm{C}$ ) was 1.57 and 1.39 , and the ratio $\tau_{\text {open }}\left(\operatorname{cap}, 50^{\circ} \mathrm{C}\right) / \tau_{\text {open }}$ (cap, $37^{\circ} \mathrm{C}$ ) was 0.81 and 0.53 . The difference between capsaicinactivated channels recorded at $37^{\circ} \mathrm{C}$ and $50^{\circ} \mathrm{C}$ is similar to the difference between heat- and capsaicin-activated channels in different patches, suggesting that the latter difference could reflect 
Table 2. Characteristics of channels activated by heat $\left(50^{\circ} \mathrm{C}\right)$ and capsaicin $(1 \mu \mathrm{M})$ in inside-out patches

\begin{tabular}{llllll} 
Stimulus & $\begin{array}{l}\operatorname{Amp}(1) \\
(\mathrm{pA})\end{array}$ & $\begin{array}{l}\operatorname{Amp}(2) \\
(\mathrm{pA})\end{array}$ & $\begin{array}{l}\text { \% of } \\
\text { openings } \\
\text { of Amp(1) }\end{array}$ & $\begin{array}{l}\% \text { of } \\
\text { openings } \\
\text { of Amp(2) }\end{array}$ & $\begin{array}{l}\text { Mean open } \\
\text { time (msec) }\end{array}$ \\
\hline Heat & $1.8 \pm 0.2$ & $3.4 \pm 0.2$ & $16.7 \pm 4.5$ & $83 \pm 4.5$ & $0.41 \pm 0.04$ \\
Capsaicin & $1.2 \pm 0.1$ & $2.8 \pm 0.15$ & $8.2 \pm 2.1$ & $92 \pm 2.1$ & $0.69 \pm 0.06$ \\
\hline
\end{tabular}

Data show mean \pm SEM of records from three patches of each type in which no multiple openings were detected. The pipette potential was $+60 \mathrm{mV}$.

Heat

Capsaicin

A

B

\section{Cس سلبلم}

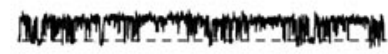

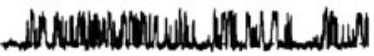

$15 \mathrm{pA}$

$25 \mathrm{msec}$

D

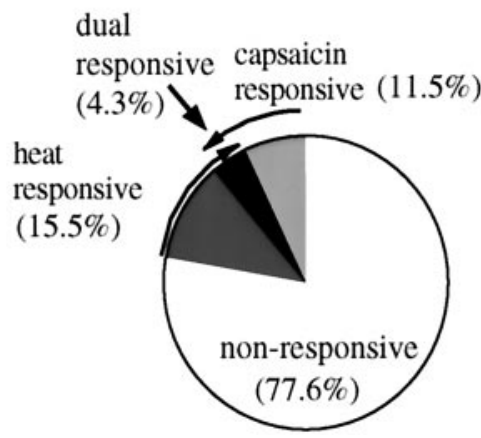

Figure 8. Lack of co-segregation of heat- and capsaicin-sensitivity at the single-channel level. $A-C$, Records from three inside-out patches that were stimulated consecutively by heat and capsaicin. Patch $A$ responded only to heat, patch $B$ responded only to capsaicin, and patch $C$ responded to both stimuli. Membrane potential was $-60 \mathrm{mV}$. Dotted lines in recordings indicate shut state. $D$, Pie chart showing percentage of heat- and capsaicin-sensitive membrane patches in a sample of 161 patches.

the effect of temperature on the channel properties, without necessarily implying that different channels are activated by the two stimuli.

To investigate directly whether heat and capsaicin activate different populations of channels, we performed experiments in which individual inside-out patches were tested successively with both stimuli. These experiments (Fig. 8) showed that of 161 patches, $18(11 \%)$ were sensitive to capsaicin and $25(15 \%)$ were sensitive to heat, but only $7(4 \%)$ responded to both stimuli. Control experiments showed that repeated application of heat or capsaicin in sensitive patches remained effective in opening channels, so the low proportion of dually responding patches could not be explained by desensitization. These data show that distinct channels respond to heat and to capsaicin. The number of dually responding patches ( 7 of 161) significantly exceeded the number expected by chance occurrence of heat- and capsaicin-sensitive channels in the same patch $\left(\chi^{2}\right.$ test, $\left.0.01<p<0.05\right)$, suggesting that some channels exhibit dual sensitivity, but the majority clearly do not.

The characteristics of heat- or capsaicin-evoked channels were similar in patches that responded to only one stimulus and in patches that responded to both (Table 2).

\section{DISCUSSION}

The purpose of these experiments was to compare the characteristics of capsaicin- and noxious heat-evoked responses of sensory neurons to throw light on the question of whether both stimuli activate the same ion channels, as suggested recently (Caterina et al., 1997; Tominaga et al., 1998).

\section{Whole-cell electrophysiology}

Our results confirm earlier reports (Cesare and McNaughton, 1996; Kirschstein et al., 1997; Reichling and Levine, 1997) that a subset of DRG neurons responds to heat with an increased cation conductance, leading to an inward current at normal resting membrane potential. The characteristics of these currents agree well with those reported by Cesare and McNaughton (1996). There are two classes of heat-sensitive DRG neurons: LT cells that also respond to capsaicin and HT cells that are insensitive to capsaicin (Nagy and Rang, 1999). In this study, we have focused on the LT population. The threshold temperature for LT cells was $\sim 45^{\circ} \mathrm{C}$, corresponding to the threshold of cutaneous nociceptors (Campbell and Meyer, 1996). The heat-activated currents in the present study had amplitudes similar to those described by Vycklicky et al. (1999) but $\sim 10$ times greater than those reported earlier (Cesare and McNaughton, 1996; Kirschstein et al., 1997; Reichling and Levine, 1997). The reason for this discrepancy is not clear but could be related to differences in experimental technique. Cesare and McNaughton (1996) studied neurons from newborn rats; Kirschstein et al. (1997) used very brief and relatively imprecise heat pulses, whereas Reichling and Levine (1997) recorded responses even at temperatures as low as $30^{\circ} \mathrm{C}$, well below the nociceptive threshold.

The reversal potential of the heat-activated current, and its ion selectivity, also agree in general with the results reported by Cesare and McNaughton (1996). Published estimates of the cation permeability of the heat-activated and capsaicin-activated channels of DRG neurons and VR1-transfected HEK cells are summarized in Table 3. All give similar values of relative $\mathrm{Cs}^{+}$ and $\mathrm{Na}^{+}$permeability of heat- and capsaicin-activated channels, but the values obtained for $\mathrm{Ca}^{2+}$ permeability vary widely. Our results suggest that $\mathrm{P}_{\mathrm{Ca}} / \mathrm{P}_{\mathrm{Na}}$ is approximately twofold greater for capsaicin- than for heat-activated channels in DRG neurons, in agreement with results of Caterina et al. (1997) and Tominaga et al. (1998) on VR1-transfected HEK cells. Because heat- and capsaicin-evoked responses were necessarily recorded at different temperatures, we cannot exclude the possibility that this could account for the difference in $\mathrm{Ca}^{2+}$ permeability. Alternatively, the nature of the stimulus-chemical or physical-could influence in a subtle way the characteristics of the open channel.

We found that capsazepine, a competitive antagonist of capsaicin, strongly antagonized the effect of capsaicin, with an $\mathrm{IC}_{50}$ close to $0.1 \mu \mathrm{M}$, but had no effect on heat-evoked currents at concentrations up to $10 \mu \mathrm{M}$. This finding agrees with the observation on DRG neurons (Reichling and Levine, 1997), but differs 


\begin{tabular}{|c|c|c|c|c|}
\hline \multicolumn{5}{|c|}{$\begin{array}{l}\text { Table 3. Relative permeabilities }\left(P_{\mathrm{Na}}=1\right) \text { to } \mathrm{Ca}^{2+} \text { and } \mathrm{Cs}^{2+} \text { of } \\
\text { heat- and capsaicin-activated channels in sensory neurons and in } \\
\text { VR1-transfected HEK cells }\end{array}$} \\
\hline \multirow[b]{2}{*}{ Stimulus } & \multirow[b]{2}{*}{ Cell } & \multicolumn{2}{|c|}{ Ion } & \multirow[b]{2}{*}{ Reference } \\
\hline & & $\mathrm{Cs}^{2+}$ & $\mathrm{Ca}^{2+}$ & \\
\hline \multirow[t]{4}{*}{ Capsaicin } & Rat DRG & $\sim 1$ & 0.24 & Oh et al., 1996 \\
\hline & Rat DRG & 1.1 & 1.9 & This paper \\
\hline & VR1-transfected & & & \\
\hline & HEK cells & 0.85 & 9.6 & $\begin{array}{l}\text { Caterina et al., } 1997 \\
\text { Cesare and }\end{array}$ \\
\hline \multirow[t]{3}{*}{ Heat } & Rat DRG & 1.24 & 1.28 & McNaughton, 1996 \\
\hline & $\begin{array}{l}\text { Rat DRG } \\
\text { VR1-transfected }\end{array}$ & 0.9 & 0.9 & This paper \\
\hline & HEK cells & & 3.8 & Tominaga et al., 1998 \\
\hline
\end{tabular}

from that of Tominaga et al. (1998) who found that $10 \mu \mathrm{M}$ capsazepine significantly reduced the heat-induced current in a VR1-expressing cell line. Ruthenium red blocked both responses at similar concentrations, but unexpectedly enhanced the heat response at $0.5 \mu \mathrm{M}$, an effect never seen on the capsaicin-induced response. In VR1-expressing non-neuronal cells, ruthenium red reduced both capsaicin- and heat-induced currents (Caterina et al., 1997; Tominaga et al., 1998); however, it did not affect the heat-evoked current in DRG neurons (Reichling and Levine, 1997), but the low-temperature threshold and the $\mathrm{Ca}^{2+}$ dependence of the current studied by Reichling and Levine (1997) suggest that those responses are different from those that we have investigated.

\section{Calcium uptake measurements}

The temperature-dependent increase in ${ }^{45} \mathrm{Ca}$ accumulation by DRG neurons resembles the action of capsaicin and shows a threshold at $\sim 46^{\circ} \mathrm{C}$. The maximal ${ }^{45} \mathrm{Ca}$ entry evoked by heat was only approximately one-third of that induced by capsaicin (Fig. 4 ), and it did not increase with temperature beyond $49^{\circ} \mathrm{C}$. The smaller maximal response to heat might have been caused by an adverse effect of high temperature on the ability of intracellular storage mechanisms to sequester calcium. However, the capsaicin-evoked ${ }^{45} \mathrm{Ca}$ entry was not affected when the temperature was raised to $49^{\circ} \mathrm{C}$. We therefore conclude that the difference in the heat- and capsaicin-evoked maximal ${ }^{45} \mathrm{Ca}$ influx could be caused by the relatively lower $\mathrm{Ca}^{2+}$ permeability of the channel during heat activation.
The results of the cell viability tests suggest that DRG neurons retain their integrity well when exposed for $10 \mathrm{~min}$ to temperatures up to $52^{\circ} \mathrm{C}$, so it is unlikely that nonspecific damage is a major factor in these experiments.

\section{Single-channel recordings}

Heat stimulation evoked single-channel activity in one-fifth of the patches taken from DRG cells. The characteristics of this singlechannel activity correspond closely with those of the heatactivated currents recorded in the whole-cell configuration. The temperature activation curve is the same shape, with a threshold of $45^{\circ} \mathrm{C}$ and steep rise at temperatures above this. The $I-V$ relationship and reversal potential of the single-channel currents also correspond with those of the whole-cell currents, suggesting that the activity of these channels underlies the heat-activated whole-cell current. Channel activity could be recorded from both excised- and cell-attached patches, showing that heat sensitivity is an integral property of the channels and is not secondary to heat-evoked modulation of intracellular signals. This conclusion agrees with the findings of Caterina et al. $(1997,1999)$ on the heat sensitivity of VR1-transfected cells, but not with the suggestion of Reichling et al. (1997) that heat-activated currents in DRG neurons are secondary to a rise in intracellular calcium concentration.

As with the whole-cell responses, there are strong similarities between the characteristics of heat- and capsaicin-evoked singlechannel currents, and our findings on the latter agree well with those of Oh et al. (1996). The $I-V$ curves and reversal potentials for capsaicin and heat agreed closely, although there were significant differences in the mean amplitude and mean open time. Compared with capsaicin-activated channels, heat-activated channels gave currents of larger amplitude and shorter duration. Such differences have not been reported on a VR1-expressing cell line (Tominaga et al., 1998). Studies on the effect of temperature on other types of ion channel [for references, see Chung and Kuyucak (1995)] show that channel conductance often shows $Q_{10}$ values of 1.3-1.5, so the difference in amplitude between capsaicin-activated and heat-activated single-channel events could be explained on this basis. The difference in mean open time could be explained similarly. Where we succeeded in measuring the effect of temperature on the characteristics of capsaicin-activated channels, the results were consistent with this interpretation

The amplitude histograms for both heat- and capsaicinactivated channels show the presence of a small proportion of low-conductance channels, which has not previously been re-

\begin{tabular}{|c|c|}
\hline Similarities & Differences \\
\hline $\begin{array}{l}\text { Co-segregation of } \mathrm{C} \text { and } \mathrm{H} \text { responses at } \\
\text { whole-cell level }\end{array}$ & $\begin{array}{l}\text { Weak correlation of amplitudes of } \mathrm{C} \text { and } \mathrm{H} \\
\text { responses }\end{array}$ \\
\hline \multicolumn{2}{|l|}{$\begin{array}{l}\text { Similar } I-V \text { curves (outward rectification) } \\
\text { for whole-cell and single-channel currents }\end{array}$} \\
\hline Nonselective increase in cation permeability & $P_{\mathrm{Ca}} / P_{\mathrm{Na}}$ greater for $\mathrm{C}$ than $\mathrm{H}$ responses \\
\hline $\mathrm{C}$ and $\mathrm{H}$ both elicit $\mathrm{Ca}$ uptake & Maximal $\mathrm{Ca}$ uptake greater for $\mathrm{C}$ than for $\mathrm{H}$ \\
\hline \multicolumn{2}{|l|}{$\begin{array}{l}\mathrm{C} \text { and } \mathrm{H} \text { both induce single-channel events } \\
\text { in excised patches }\end{array}$} \\
\hline $\begin{array}{l}\text { Similar single-channel characteristics (ampli- } \\
\text { tude, mean open time, substate level) }\end{array}$ & $\begin{array}{l}\text { Segregation of sensitivity to } \mathrm{C} \text { and } \mathrm{H} \text { at } \\
\text { single-channel level }\end{array}$ \\
\hline
\end{tabular}


ported. It is difficult to be certain whether these represent distinct channels or a subconductance state of a single type of channel. If there were two distinct types of channel, occasional dual (high plus low) openings would be expected. These were not detected, but typically the total open probability was $\sim 0.2$ (corresponding to $\sim 0.17$ for the large channels and 0.03 for the small channels); the probability of both being open simultaneously would therefore be only $\sim 0.005$, and such events could easily have been missed. Occasional low-high and high-low transitions were detected, as expected if the two levels represent distinct conductance states of the same channels, but a more rigorous analysis would be needed to establish this point. The open-time histograms showed only a single component. Separating the channels into low and high conductance events gave similar mean open times for each, so we were not able to distinguish between them on this basis.

Our most unexpected finding was that most patches responded to either heat or capsaicin, but rarely to both. It was important to be sure that the separation of heat and capsaicin sensitivity was not an artifact attributable to desensitization. Control experiments showed that repetition of either stimulus, although resulting in progressive reduction of the response, never caused complete desensitization. Furthermore, it was frequently found that patches that failed to respond to the first test would respond to the second, after switching from heat to capsaicin, or vice versa. We therefore conclude that distinct channels respond to heat and capsaicin, respectively. The number of dual-sensitive patches somewhat exceeded the number expected by chance. This could reflect the presence of some individual channels that respond to both stimuli or a tendency for channels of both types to aggregate in the same patch of membrane.

The work of Caterina et al. (1997) and Tominaga et al. (1998) shows that transfection of HEK293 cells with the VR1 gene results in the appearance of both heat- and capsaicin-sensitive channels, but it remains to be established whether an individual channel responds to both stimuli. The most economical explanation to reconcile our findings would be that the VR1 gene product may assume different functional states depending on other factors, including splice variants, aggregation with other membrane proteins, the presence of different multimeric species, or the degree of phosphorylation or glycosylation of the channel protein.

The similarities and differences between heat- and capsaicinevoked responses presented in this paper are summarized in Table 4.

\section{REFERENCES}

Bevan SJ, Docherty RJ (1993) Cellular mechanisms of the action of capsaicin. In: Capsaicin in the study of pain (Wood JN, ed), pp 27-44. London: Academic.

Bevan SJ, Szolcsanyi J (1990) Sensory neuron-specific actions of capsaicin: mechanisms and applications. Trends Pharmacol Sci 11:330-333.

Bevan S, Hothi S, Hughes G, James IF, Rang HP, Shah K, Walpole CSJ, Yeats JC (1992) Capsazepine: a competitive antagonist of the sensory neurone excitant capsaicin. Br J Pharmacol 107:544-552.

Campbell JN, Meyer RA (1996) Cutaneous nociceptors. In: Neurobiology of nociceptors (Belmonte CF, Cervero F, eds), pp 117-145. Oxford: Oxford UP.

Caterina MJ, Schumacher MA, Tominaga M, Rosen TA, Levine JD, Julius D (1997) The capsaicin receptor: a heat-activated ion channel in the pain pathway. Nature 389:816-824.
Caterina MJ, Rosen TA, Tominaga M, Brake AJ, Julius D (1999) A capsaicin-receptor homologue with a high threshold for noxious heat. Nature 398:436-441.

Cesare P, McNaughton P (1996) A novel heat-activated current in nociceptive neurons and its sensitization by bradykinin. Proc Natl Acad Sci USA 93:15435-15439.

Chung S-H, Kuyucak S (1995) Changes in the conductance and kinetics of $N$-methyl-D-aspartate (NMDA)-receptor activated single channels with temperature. Neurosci Lett 187:181-184.

Colquhoun D, Sigworth FJ (1995) Fitting and statistical analysis of single channel records. In: Single channel recording (Sakmann B, Neher E, eds), pp 397-482. New York: Plenum.

Dray A, Forbes CA, Burgess GM (1990) Ruthenium red blocks the capsaicin-induced increase in intracellular calcium and activation of membrane currents in sensory neurones as well as the activation of peripheral nociceptors in vitro. Neurosci Lett 110:52-59.

Hammill OP, Marty A, Neher E, Sakmann B, Sigworth FJ (1981) Improved patch-clamp techniques for high-resolution current recording from cells and cell-free membrane patches. Pflügers Arch 391:85-100.

Hille B (1992) Ionic channels of excitable membranes. Sunderland, MA: Sinauer.

Kirschstein T, Busselberg D, Treede RD (1997) Coexpression of heatevoked and capsaicin-evoked inward currents in acutely dissociated rat dorsal root ganglion neurons. Neurosci Lett 231:33-36.

Leaney JL, Marsh SJ, Brown DA (1977) A swelling-activated chloride current in rat sympathetic neurones. J Physiol (Lond) 501:555-564.

Lewis CA (1979) Ion concentration dependence of the reversal potential and the single channel conductance of ion channels at the frog neuromuscular junction. J Physiol (Lond) 86:417-445.

Lindsay RM (1988) Nerve growth factors (NGF, BDNF) enhance axonal regeneration but are not required for survival of adult sensory neurons. J Neurosci 8:2394-2405.

Maggi CA, Bevan S, Walpole CS, Rang HP, Giuliani S (1993) A comparison of capsazepine and ruthenium red as capsaicin antagonists in the rat isolated urinary bladder and vas deferens. Br J Pharmacol 108:801-805.

Michael GJ, Priestley JV (1999) Differential expression of the mRNA for the vanilloid receptor subtype 1 in cells of the adult rat dorsal root and nodose ganglia and its downregulation by axotomy. J Neurosci 19:1844-1854.

Nagy I, Rang HP (1997) Noxious heat-activated currents in rat dorsal root ganglion neurons. J Physiol (Lond) 506:153P.

Nagy I, Rang HP (1998) Noxious heat-activated microscopic currents in rat dorsal root ganglion neurones. J Physiol (Lond) 607:29P.

Nagy I, Rang HP (1999) Noxious heat activates all capsaicin-sensitive and also a sub-population of capsaicin-insensitive dorsal root ganglion neurons. Neuroscience 88:995-997.

Oh U, Hwang SW, Kim D (1996) Capsaicin activates a non-selective cation channel in cultured rat dorsal root ganglion neurons. J Neurosci 16:659-1667.

Reichling DB, Levine JD (1997) Heat transduction in rat sensory neurons by calcium-dependent activation of a cation channel. Proc Natl Acad Sci USA 94:7006-7011.

Szallasi A, Blumberg PM (1990) Specific binding of resiniferatoxin, an ultrapotent capsaicin analog, by dorsal root ganglion membranes. Brain Res 524:106-121.

Szolcsanyi J, Anton F, Reeh PW, Handwerker HO (1988) Selective excitation by capsaicin of mechano-heat sensitive nociceptors in rat skin. Brain Res 446:262-268.

Tominaga M, Caterina MJ, Malmberg AB, Rosen TA, Gilbert H, Skinner K, Raumann BE, Basbaum AI, Julius D (1998) The cloned capsaicin receptor integrates multiple pain-producing stimuli. Neuron 21:531-543.

Vycklicky L, Vlachova V, Vitaskova Z, Dittert I, Kabat M, Orkand RK (1999) Tempreature coefficient of membrane currents evoked by noxious heat in sensory neurones of the rat. J Physiol (Lond) 517:181-192.

Wood JN, Winter J, James IF, Rang HP, Yeats J, Bevan S (1988) Capsaicin-induced ion fluxes in dorsal root ganglion cells in culture. J Neurosci 8:3208-3220. 